\title{
2009 Ortaöğretim Müzik Dersi Öğretim Programı İle 2018 Ortaöğretim Müzik Dersi Öğretim Programının Karşılaştırılmalı Kuramsal Çerçeve Analizi
}

\author{
The Comparative Theoretical Framework Analysis of the 2009 Secondary \\ Music Course Teaching Program and 2018 Secondary Music Course Teaching \\ Program
}

\author{
Aytekin Albuz \\ Prof. Dr., Gazi Üniversitesi Gazi Eğitim Fakültesi Güzel Sanatlar Eğitimi Bölümü Müzik Eğitimi Ana Bilim Dalı, \\ aytekina@gazi.edu.tr
}

\section{Serkan Demirel}

Doktora Öğrencisi, Gazi Üniversitesi Gazi Eğitim Fakültesi Güzel Sanatlar Eğitimi Bölümü Müzik Eğitimi Ana Bilim Dalı, sekole@gmail.com

\section{$\ddot{O} \mathbf{z}$}

Gelişmiş toplumların eğitim sistemlerine verilen önem, hem ülkenin yaşam kalitesini artırmakta hem de gelişmekte olan toplumlara bir çok açıdan 1şık tutmaktadır. Eğitim sistemleri üzerine yapılan araştırmalar bunların hem bir sonucu hem de bir gerekliliğidir. Öğrenci merkezli yaklaşımlar, özellikle son yıllarda popülaritesini arttırmış, karma sistemlerin bile omurgalarını oluşturmuştur. Ayrıca, bilimin kümülatif bir alan olması nedeniyle, eğitim bilimleri kapsamında, bir önceki bilgileri kullanarak yeni bilgiler ortaya koymak amacıyla eğitim sistemleri planlanmıştır.

2009 yılında uygulamaya giren ortaöğretim müzik dersi öğretim programı, 2018 yılında yeniden ele alınarak güncellenmiş ve yürürlüğe girmiştir. Araştırmanın amacı ise, söz konusu iki programı karşılaştırmalı olarak incelemek ve bu incelemeler 1şı̆̆ında değerlendirmeler yapmaktır. Karşılaştırmalı incelemeler ve analizler, hem program geliştirme süreçleri esnasında hem de uygulama süresince programın yapısını ortaya koyup uygulanabilirliğini, gerekirse daha iyi bir hale getirilmesine olanak sağlaması yönüyle önem arz etmektedir.

Araştırma sonucunda, elde edilen bulgular eşliğinde analizler yapılmıştır. Araştırmada, 2009 ortaöğretim müzik dersi öğretim programı ve 2018 ortaöğretim müzik dersi öğretim programında birçok bakımdan benzerlikler ortaya konurken bazı farklılıklar da gözlemlenmiştir. 2009 ortaöğretim müzik dersi öğretim programında "söyleme-çalma ve dinleme" öğrenme alanları bulunmakta iken, 2018 ortaöğretim müzik dersi öğretim programında "çalma" öğrenme alanı çıartılıış, "söyleme-dinleme" öğrenme alanı olarak birleştirilmiştir.

Anahtar Kelimeler: Öğretim Programı, Program Analiz

\begin{abstract}
The importance of the education systems in the developed societies not only increases the quality of life of the country but also sheds light on many aspects of developing societies. The researches on educational systems are both the consequences and the necessities for them. Student-centered
\end{abstract}


approaches have increased their popularity especially in recent years and have even formed backbones of the mixed systems. In addition, due to the fact that science is a cumulative field, within the scope of educational sciences, educational systems are planned in order to reveal new information by using the previous information.

The secondary school music course curriculum of 2009 has been reconsidered and introduced in 2018 . The aim of the study is to examine these two programs comparatively and to make evaluations based on these examines. The comparative reviews and analysis reveal the structure of the program and its applicability. It is important in terms of allowing it to be improved during not only development and planning process but also during application process.

As a result of the research, the findings were analyzed. In the study, some similarities and some differences have been observed in many respect between 2009 education curriculum and 2018 secondary education music curriculum. "Singing, playing, and listening" learning areas in 2009 secondary school music curriculum was changed in 2018 secondary school music course curriculum, and "playing" taken out and it was combined as "singing-listening" learning area.

Keywords: Music Teaching Program, Program Analysis

\section{Giriş}

Eğitimde gittikçe önem kazanan modern yaklaşımlar etkili ve kalıcı bir öğrenmenin nasıl sağlanacağı yönünde çeşitli araştırmaların yapılmasının önünü açmıştır. Günümüzde artık bilginin büyük ölçüde öğretmen merkezli aktarımının çağın gereklerine uymadığı bilinen bir gerçektir. Ancak bu durum öğretmenin rolünü hiçbir zaman ikinci plana atmayıp aksine kendisine öğretim süreçlerinde aktif rol alma firsatı sunmaktadır. Artık öğrencinin bilgiye ulaşmasını ve kalıcılığa yönelik yapılandırmasını kolaylaştırıcı yöntemlerin geliştirilmesinin önemi üzerinde durulmakta ve öğretim programları bu temel üzerine inşa edilmektedir.

Program kelimesinin tarihsel olarak başlangıç zamanı ile birtakım karmaşalar bulunmasına rağmen, Türkiye'de, özellikle Cumhuriyet döneminde eğitimde yapılan yenilikler ile birlikte, yoğun olarak kullanılmaya başlandığı bilinmektedir. Bununla birlikte program kavramına ilişkin önde gelen araştırmacıların ifadeleri;

"Kişide, istenilen hedeflerin ve bu hedefleri gerçekleştirmek için planlanan sürecin bir bütünü (Sönmez, 2005, s. 7), geçerli bir öğrenme yaşantısı planı (Ertürk, 1979, s. 95), eğitim kurumunun, öğrencileri yetiştirmek için amaçlarının gerçekleştirilmesini kapsayan tüm faaliyetler (Varış, 1994, s. 18)" şeklinde tanımlanmıştır.

Demirel (2007, s. 1)’ e göre eğitim programı,

- Konular listesidir

- Ders içerikleridir

- Çalışmaların programlanmasıdır

- Öğretim materyalleri listesidir

- Derslerin siralanmasidir

- Hedef davranışlar grubudur 
- Okul içinde ve dışında öğretilen herşeydir.

- Okul personeli tarafından planlanan herşeydir.

Görüldüğü gibi, program tanımlarının ortak noktası, belli bir amaç doğrultusunda bir kazanım elde etmek için planlama aşamasını da kapsayan bir bütün olarak dikkat çekmektedir. Erden (1995, s. 11)' e göre, nitelikli eğitim için eğitim programı eğitim kurumunun en önemli uğraşı olmalıdır. Uygulanan programlardaki aksaklıklar zamanla düzeltildikçe yani geliştirildikçe eğitimin niteliğinin artmas1 beklenir. Programın eğitim kavramı ile iç içe geçmiş noktaları da bulunmaktadır. Eğitim ile ilgili tanımlardan bazılarını ele almak gerekirse;

"Eğitim, bireyin davranışlarında kendi yaşantısı yoluyla ve kasıtlı olarak, istendik davranış değişikliği meydana getirme sürecidir" (Ertürk, 1979, s. 77). "Eğitim, bireyin doğumundan ölümüne kadar süre gelen bir süreçtir" (Erden, 1998, s. 13).

Program ve eğitim tanımlarından da anlaşılabileceği gibi, eğitimde program kavramı en temel unsurdur. Diğer bir ifade ile bir programın geliştirilmesi, eğitimin vazgeçilmez bir unsurudur. Program geliştirme en genel anlamıyla "eğitim programlarının tasarlanması, uygulanması, değerlendirilmesi ve değerlendirilme sonucu elde edilen veriler doğrultusunda yeniden düzenlenmesi sürecidir" (Erden, 1998, s. 4).

Eğitim programlarının değerlendirme aşamasında belli başlı değerlendirme modelleri kullanılmaktadır. $\mathrm{Bu}$ modellerden öne çıkan modeller şunlardır;

- Hedefe dayalı program değerlendirme

- Stufflebeam' in çevre girdi, süreç ve ürün modeli

- Eğitsel eleştiri modeli (Albuz, 2004, s. 15).

İlk iki modelde niceliksel olarak inceleme ön plana çıkarken, eğitsel eleştiri modeli daha çok niteliksel incelemeyi ön plana çıkarmaktadır. Bu kapsamda program geliştirmenin aşamaları; program hazırlama, program deneme, program değerlendirme ve program düzeltme safhalarından oluşmaktadır.

$\mathrm{Bu}$ araştırmanın da temeli içinde göz önünde bulundurulmuş olan program değerlendirmenin başlıca kriterleriyse şunlardır;

- Program hazırlama ilkelerine uygunluk

- Çağdaş program anlayışına uygunluk

- Program geliştirme modeline uygunluk

- Kullanılan modelin geçerliği

- Modelin tasariya uygunluğu (Albuz, 2004, s. 16).

Programların uygulanma aşamasında, öğrenme yaklaşımları açısından da önemli gelişmeler meydana gelmiştir. Özellikle yapılandırmacı öğrenme yaklaşımının git gide önem kazandığı bu günlerde, öğretmenin rolü de büyük önem taşımaktadır. "Çağdaş dünyanın kabul ettiği birey, kendisine aktarılan bilgileri aynen kabul eden, yönlendirilmeyi ve biçimlendirilmeyi bekleyen değil, bilgiyi yorumlayarak anlamının yaratılması sürecine etkin olarak katılandır" (Yıldırım ve Akar, 1999, s. 35).

"Yapılandırmacı yaklaşımda, programlardan daha önemli olan şey, öğrencinin hazırbuluşluk düzeyidir. Öğrenci merkeze alınmalı, problem çözmesine olanak ve firsat verilmelidir; çünkü öğrenecek olan kendisidir. İçerik bunu sağlayacak biçimde çok çeşitli olarak ona sunulmalıdır” (Sönmez, 2010, s. 148). 
Brooks ve Brooks (1999, s. 18-24)'e göre, “Anlama arayış1 öğrencileri öğrenmeye motive eder. Öğrenciler bir fikir, bir konu veya disiplinin tamamı hakkında daha fazla bilgi edinmek istediklerinde sınıf içi araştırmalara ve tartışmalara daha bilişsel enerji koyarlar ve kendi başlarına daha fazla çalışırlar".

Bununla birlikte Brooks ve Brooks 5 ana yapılandırmacı prensip belirleyerek yapılandırmacı yaklaşımda öğretmenin yapması gerekenleri şu şekilde vurgulamıştır;

- Yapılandırmacı öğretmenler öğrencilerin bakış açılarını araştırır ve değer verir. Öğrencilerin kavramlar hakkında ne düşündüğünü bilmek, öğretmenlerin sınıf içi dersleri formüle etmesine ve öğretimi öğrencilerin ihtiyaçları ve ilgi alanlarına göre farklılaştırmasına yardımcı olur

- Yapılandırmacı öğretmenler öğrencilerin varsayımlarını zorlamak için dersleri yapılandırır. Kaç yaşında olursa olsun, tüm öğrenciler sınıfa dünyalarının nasıl çalıştığıyla ilgili görüşlerini şekillendiren yaşam deneyimleriyle gelirler. Eğitimciler, öğrencilerin mevcut varsayımlarını zorlayan bilgiler oluşturmalarına izin verdiğinde, öğrenme gerçekleşir. Sadece öğrencilere bildiklerini düşündüklerini ve neden bizim bildiğimizi düşündüklerini sorarak onların varsayımlarıyla yüzleşebileceklerini sorarlar.

- Yapılandırmacı öğretmenler öğrencilerin müfredata uygunluk katması gerektiğini kabul etmektedir. Öğrenciler günlük aktivitelerinde alaka düzeyini gördükçe, öğrenmeye ilgileri de artar.

- Yapılandırmacı öğretmenler küçük bilgi parçaları yerine büyük fikirler etrafında dersleri yapılandırırlar. Öğrencileri ilk seferinde tamamen bilgiye maruz bırakmak, o fertleri daha iyi anlamaları için ilgili bölümleri belirlemelerine yardımcı olur.

- Yapılandırmacı öğretmenler öğrencinin öğrenmesini ayrı olaylar olarak değil, günlük sınıf incelemeleri bağlamında değerlendirir. Öğrenciler bilgilerini her gün çeşitli şekillerde gösterirler. Anlayışı, yalnızca sıkı güvenlik altında yönetilen kâğıt kalemle değerlendirmelerle ölçülebilen olarak tanımlamak, akademi, istihbarat, yaratıcılık, hesap verebilirlik ve bilgi hakkındaki yanlış ve üretken mitleri sürdürür (Brooks \& Brooks, 1999, s. 18-24).

Eğitimin ve programların tanımları üzerine yapılan değerlendirmelere, müzik eğitimi özelinde de değerlendirmeler yapılmıştır. Bu değerlendirmeler, eğitim genelinde ortak ifadelere yer verildiği, özelde ise müzik eğitiminin amaç ve hedefleri kapsamında teknik ifadelere yer verildiği görülmüştür.

Uçan (2005, s. 14) müzik eğitimini, "bireye kendi yaşantısı ile belirli istendik davranışlar kazandırma" şeklinde ifade etmektedir. Eğitimin de bu ortak ifadeyi kullanması bakımından, eğitimin programlı olması gerekliliği, müzik eğitiminin de planlı programlı yapılması gerekliliğini ortaya koymaktadır. "Müzik eğitimi, program ayrımı gözetmez, herhangi bir aşamada, herhangi bir düzeyde, yaşam için asgari müzik kültürü kazandırmayı hedefleyen dengeli ve sağlıklı bireyler yetiştirmeyi hedefler" (Uçan, 2005, s. 31). Müzik eğitiminin boyutları, ses eğitimi, müziksel işitme eğitimi, müzik beğenisi eğitimi, yaratıcılık eğitimi ve çalgı çalma eğitimi olarak ele alınmaktadır (Bilen,1995, s. 14).

Bu bağlamda, 2009 ve 2018 ortaöğretim müzik dersi öğretim programları, öğrenci merkezli yapılandırılmış, öğrencinin müziği nasıl daha iyi öğreneceğine odaklanmış bir yaklaşımdır.

Araştırmaya konu olan 2009 ortaöğretim müzik dersi öğretim programı, 2018 yılında tekrar güncellenmiştir. Bu çalışmada karşılaştırmalı analiz yapılarak ele alınmış, bulgular ve değerlendirmeler yapılmıştır. Her iki programın karşılaştırılması, kullanılan öğrenme yaklaşımları, öğrenme alanları, öğrenme alanlarına ilişkin kazanımların türü ve ele alınış biçiminin değerlendirilmesi bakımından önem arz etmektedir. 


\section{Yöntem}

\subsection{Araştırmanın Deseni}

Betimsel bir model benimsenen bu araştırma, genel tarama modelinde karş1laştırmalı alan araştırması üzerine kurgulanmıştır. Bu kapsamda, 2009 Ortaöğretim müzik dersi öğretim programı (MEB, 2009, s. 1-163) ve 2018 ortaöğretim müzik dersi öğretim programının (MEB, 2018, s. 1-37) ölçüm cetvelleri oluşturularak, araştırma yapılmıştır.

\subsection{Verilerin Toplanması}

Literatür taraması ve araştırma verilerinin toplanmasında döküman incelemesi tekniği kullanılmıştır. 2009 Ortaöğretim müzik dersi öğretim programı ve 2018 ortaöğretim müzik dersi öğretim programı, doküman olarak ele alınmış, gerekli sınıflandırmalar yapılarak araştırmada kullanılmak üzere toplanmiştır.

\subsection{Veri Analizi}

Araştırma verilerinin çözümlenmesinde içerik analizi tekniği kullanılmıştır. "İçerik analizinde yapılan işlem, birbirine benzeyen verileri belirli kavramlar ve temalar çerçevesinde bir araya getirmek ve bunları okuyucunun anlayabileceği bir biçimde düzenleyerek yorumlamaktır" (Yıldırım ve Şimşek, 2013, s. 259). Bu kapsamda, 2009 Ortaöğretim müzik dersi öğretim programı ve 2018 ortaöğretim müzik dersi ögretim programı, birbirini izleyen iki program olduğu için benzer ifadeler sınıflandırılıp araştırmanın amaçları kapsamına uygun analiz yapılmıştır.

\section{Bulgular ve Yorum}

2009 ortaöğretim müzik dersi öğretim programı ve 2018 ortaöğretim müzik dersi öğretim programlarının karşılaştırmalı analiz ve değerlendirmeleri aşağıda yer almaktadır.

Tablo 1

2009 Ortaöğretim Müzik Dersi Öğretim Programı ve 2018 Ortaöğretim Müzik Dersi Öğretim Programlarının Biçimsel Açıdan Karşılaştırılması

\begin{tabular}{|c|c|}
\hline 2009 Ortaöğretim Müzik Dersi Öğretim Programı & 2018 Ortaöğretim Müzik Dersi Öğretim Programı \\
\hline 2010-2017 yılları arasında 6 yıl süresince yürürlükte kalmıştır. & 2018 de yürürlüğe girmiş olup halen sürmektedir. \\
\hline Program hazırlayan uzmanların isimleri programda yer almaktadır & Programı hazırlayan uzmanlar, ders kitabında yer almaktadır. \\
\hline $\begin{array}{l}\text { Uygulama sürecinde ders kitabı materyali yürürlükten } \\
\text { kaldırılmıştır. }\end{array}$ & Ders kitabı mevcuttur. \\
\hline Müfredat programı görümündedir & Müfredat programı görümündedir \\
\hline $\begin{array}{l}\text { Öğrenci merkezli eğitim ve aktif öğrenme yaklaşımlarından } \\
\text { hareketle öğrencilerin yaparak yaşayarak öğrenmelerini } \\
\text { amaçlanmıştır. }\end{array}$ & Öğrenci merkezli eğitim öne çıkmaktadır \\
\hline $\begin{array}{l}\text { Programda Öğrenme alanları ve kazanımlar açı şekilde } \\
\text { belirtilmiştir. }\end{array}$ & $\begin{array}{l}\text { Programda Öğrenme alanları ve kazanımlar açı şekilde } \\
\text { belirtilmiştir. }\end{array}$ \\
\hline Programda Genel amaçlar açık şekilde verilmiştir. & Programda Genel amaçlar açık şekilde verilmiştir. \\
\hline $\begin{array}{l}\text { Türk Milli Eğitiminin Genel Amaçları ile başlamakta olup müzik } \\
\text { dersi programı için ayrı bir genel amaçlar başlığı ayrıca bilgi } \\
\text { verilmektedir. }\end{array}$ & $\begin{array}{l}\text { Milli eğitim Bakanlığı Öğretim programları ile ilgili bilgi ile } \\
\text { başlayıp sonrasında öğretim programlarının amaçları konusunda } \\
\text { bilgi verilmektedir. }\end{array}$ \\
\hline $\begin{array}{l}\text { Programda, programın misyonu, programın vizyonu, programın } \\
\text { temel yaklaşımı bulunmaktadır. }\end{array}$ & $\begin{array}{l}\text { Programda, öğretim programlarının perspektifi, "değerlerimiz, } \\
\text { yetkinlikler," başlıklarıyla vurgulanmıştır. }\end{array}$ \\
\hline $\begin{array}{l}\text { Programın uygulanması ile ilgili açıllamaların yanı sıra öğretim } \\
\text { yöntem ve teknikleri içerisinde genel müzik öğretim yöntemleri ve } \\
\text { özel müzik ögrretim yöntemleri alt başlığında öğretim yöntem ve } \\
\text { tekniklerine yer verilmiştir. }\end{array}$ & $\begin{array}{l}\text { Müzik Dersi Öğretim Programı'nın Uygulanmasında Dikkat } \\
\text { Edilecek Hususlara yer verilmiştir. }\end{array}$ \\
\hline Kazanım ifadeleri öğrenci merkezlidir & Kazanım ifadeleri öğrenci merkezlidir \\
\hline e yer verilmiştir. & Örnek ders işleyişine yer verilmemiştir. \\
\hline Programda ölçme değerlendirme ile ilgili örneğe yer verilmiştir. & Programda ölçme değerlendirme ile ilgili örneğe yer verilmemiştir. \\
\hline 167 sayfadan oluşmaktadır & \\
\hline $\begin{array}{l}\text { Programda özel ihtisas komisyonunun isimleri bulunmaktadır. } \\
\text { Programda kaynakçaya yer verilmiştir. }\end{array}$ & $\begin{array}{l}\text { Programda özel ihtisas komisyonunun isimleri bulunmamaktadır. } \\
\text { Programda kaynakçaya yer verilmemiştir. }\end{array}$ \\
\hline
\end{tabular}


Tablo 1'de görüldüğü üzere, iki programda öğrenci merkezli olup kazanımlar ve öğrenme alanları açıkça belirtilmiştir. Programın yapısı ve işleyişi ile ilgili bilgiler iki programda da verilmiştir. 2009 ortaöğretim müzik dersi öğretim programında bulunan örnek etkinlikler, ölçme değerlendirme örneği 2018 ortaöğretim müzik dersi öğretim programında görülmemektedir. Bu sebeple sayfa yapısı olarak büyük bir fark ortaya çıkmıştır. 2018 ortaöğretim müzik dersi öğretim programında bulunan bu eksiklik ders kitabıyla giderilmiştir. Ayrıca, kaynakça ve ihtisas komisyonu 2018 ortaöğretim müzik dersi öğretim programında gözlemlenememiştir.

Tablo 2

2009 Ortaöğretim Müzik Dersi Öğretim Programı ve 2018 Ortaöğretim Müzik Dersi Öğretim Programlarının Programın Temel Yapısı ve Öğrenme Alanları Boyutunda Karşılaştırılması

\begin{tabular}{|c|c|}
\hline 2009 Ortaöğretim Müzik Dersi Öğretim Programı & 2018 Ortaöğretim Müzik Dersi Öğretim Programı \\
\hline $\begin{array}{l}\text { Programın Temel Yapısı ve Öğrenme Alanları } \\
2009 \text { Ortaöğretim Müzik Dersi Öğretim Programı, öğrencilerin ilgi } \\
\text { ve ihtiyaçlarına cevap verecek, Türk Millî Eğitiminin Genel } \\
\text { Amaçları na uygun, çağın gerektirdiği toplumsal düzeyin } \\
\text { gelişimine hizmet edecek şekilde aşağıda belirtilen beş temel } \\
\text { öğrenme alanı üzerine kurulmuştur. } \\
\text { Ortaöğretim Müzik Dersi Öğretim Programı öğrenme alanları } \\
\text { şunlardır: }\end{array}$ & $\begin{array}{l}\text { Programın Temel Yapısı ve Öğrenme Alanları } \\
2018 \text { Ortaöğretim müzik dersi öğretim Programı'nda öğrenme alanı } \\
\text { temelli yaklaşım esas alınmıştır. Programda her sınıf düzeyinde } \\
\text { aşağıdaki dört ögrenme alanı yer almaktadır. } \\
\text { Programında yer alan kazanımlar öğrenme alanlarına göre } \\
\text { numaralandırılmıştır. Kazanımlar, programın içinde; ders kodu, } \\
\text { sınıf düzeyi, öğrenme alanı ve kazanım numarası olarak ifade } \\
\text { edilmiş ve aşağıda şema-tik olarak gösterilmiştir. }\end{array}$ \\
\hline $\begin{array}{ll}\text { - } & \text { Söyleme-Çalma } \\
\text { - } & \text { Dinleme } \\
\text { - } & \text { Müziksel Algı ve Bilgilendirme } \\
\text { - } & \text { Müziksel Yärärı̈ } \\
\end{array}$ & $\begin{array}{ll}\text { - } & \text { Dinleme-Söyleme } \\
\text { - } & \text { Müziksel Algı veBilgilenme } \\
\text { - } & \text { Müziksel Yaratıcılık } \\
\text { Müzik Kültürü }\end{array}$ \\
\hline
\end{tabular}

Tablo 2'de programların temel yapıları ve öğrenme alanlarına yer verilmiştir. Müziksel algı ve bilgilenme, müzik kültürü, müziksel yaratıcılık iki programın ortak öğrenme alanlarıdır. 2009 ortaöğretim müzik dersi öğretim programında söyleme-çalma ve dinleme ayrı öğrenme alanları olarak yer alırken, 2018 ortaöğretim müzik dersi öğretim programında çalma yer almamış, dinleme- söyleme olarak değiştirilmiştir.

Tablo 3

2009 Ortaögretim Müzik Dersi Öğretim Programı ve 2018 Ortaögrretim Müzik Dersi Öğretim Programlarının Özel Amaçlar Boyutunda Karşılaştırılması

\begin{tabular}{|c|c|}
\hline 2009 Ortaöğretim Müzik Dersi Öğretim Programı & 2018 Ortaöğretim Müzik Dersi Öğretim Programı \\
\hline Ortaöğretim Müzik Dersi Öğretim Programının Genel Amaçları & MüzikDersiÖğretimProgramı'nınÖzelAmaçları \\
\hline $\begin{array}{l}\text { 1. İstiklal Marşı’mızla beraber millî birlik ve bütünlüğümüzü } \\
\text { pekiştiren diğer marşlarımızı da doğru ve etkili } \\
\text { seslendirmenin önemini benimsemeleri, }\end{array}$ & $\begin{array}{l}\text { 1. İstiklâl Marşı'mızla beraber millî birlik ve bütünlüğümüzü } \\
\text { pekiştiren diğer marşlarımızı doğru ve etkili seslendirmeleri, }\end{array}$ \\
\hline Türkçeyi doğru ve etkili kullanmaları, & $\begin{array}{l}\text { 2. Müzik alanında yapılan çalışmaları ve gelişmeleri takip } \\
\text { etmeleri, }\end{array}$ \\
\hline $\begin{array}{l}\text { Atatürk’ün müzik görüşleri doğrultusunda yapılan } \\
\text { çalışmalarla ulaşılan aşamaları takip etmeleri, }\end{array}$ & $\begin{array}{l}\text { 3. Müziğe yönelik olumlu tutum sergileyerek özgüvenini ve } \\
\text { yaratıcılığını geliştirmeleri }\end{array}$ \\
\hline İyiye ve güzele yönelerek iyi alışkanlıklar edinmeleri, & $\begin{array}{l}\text { 4. İlgiveyeteneğidoğrultusundamüziketkinliklerine(şarkısöyleme, } \\
\text { yaratıcıçalışmalar, araştırma) yönelmeleri, }\end{array}$ \\
\hline Anlama, anlatma ve yaratma gücünü geliştirmeleri, & Müziksel bilgi, görgü, ilgi, istek ve yeteneklerini geliştirmeleri, \\
\hline Entelektüel merakını geliştirmeleri, & Müzik terminolojisini ve dilini doğru kullanmaları, \\
\hline $\begin{array}{l}\text { Müziğe yönelik olumlu tutum sergileyerek öz güvenini ve } \\
\text { yaratıcılığını geliştirmeleri, }\end{array}$ & $\begin{array}{l}\text { Müzikselalgıve bilgilenme ile müziksel temel okuma ve yazma } \\
\text { becerisine sahip olmaları, }\end{array}$ \\
\hline $\begin{array}{l}\text { Araştırma yapma, bilgi üretme ve bilgiyi kullanma gücünü } \\
\text { geliştirmeleri, }\end{array}$ & $\begin{array}{l}\text { Müziğin diğer sanat dallarıyla ilişkisini kurarak estetik } \\
\text { duygularını geliştirmeleri, }\end{array}$ \\
\hline $\begin{array}{l}\text { 9. İlgi ve yeteneği doğrultusunda müzik etkinliklerine } \\
\text { yönelmeleri (şarkı söyleme, çalgı çalma, yaratıcı çalışmalar, } \\
\text { araştırma), }\end{array}$ & Bilinçli bir müzik dinleyicisi olmaları, \\
\hline $\begin{array}{l}\text { 10. Müziksel bilgi, görgü, ilgi, istek ve yeteneğini geliştirmeleri, } \\
\text { 11. Müzik terminolojisini ve dilini doğru kullanmaları, } \\
\text { 12. Müziksel algı ve bilgilenme ile müziksel temel okuma ve } \\
\text { yazma becerisine sahip olmaları, }\end{array}$ & $\begin{array}{l}\text { 10. Müzik dağarcığı oluşturmaları, } \\
\text { 11. Ülkemizdeki müzik türlerini ve önemli sanatçıları tanımaları, } \\
\text { 12. Evrensel bir müzik kültürüne sahip olmaları } \\
\text { amaçlanmaktadır. }\end{array}$ \\
\hline
\end{tabular}


13. Müziğin diğer sanat dallarıyla ilişkisini kurarak estetik duygularını geliştirmeleri,

14. Bilinçli bir müzik dileyicisi olmaları,

15. Müzik dağarcığı oluşturmaları,

16. Ülkemiz müzik türleri ile birlikte evrensel bir müzik kültürüne sahip olmaları amaçlanmaktadır.

Tablo 3'de de görüldüğü gibi 2009 ortaöğretim müzik dersi öğretim programı ve 2018 ortaöğretim müzik dersi öğretim programı genel hatlarıyla, dersin amaçları doğrultusunda birbirine benzemektedir. Bununla beraber 2009 ortaöğretim müzik dersi öğretim programında bulunan " 3 , 4, 5 ve 8 " numaralı dersin amaç başlıkları, 2018 ortaöğretim müzik dersi öğretim programında birebir bulunmamaktadır.

Tablo 4

2009 Ortaögretim Müzik Dersi Öğretim Programı ve 2018 Ortaögretim Müzik Dersi Öğretim Programlarının İçeriksel Açıdan Karşıllaştırılması

\begin{tabular}{|c|c|}
\hline 2009 Ortaöğretim Müzik Dersi Öğretim Programı & 2018 Ortaöğretim Müzik Dersi Öğretim Programı \\
\hline Yapılandırmacı yaklaşım benimsenmiştir & Yapılandırmacı yaklaşım benimsenmiştir. \\
\hline $\begin{array}{cl}\text { Programın modeli; Beş Boyutlu Çağdaş Öğretim Programı } \\
\bullet \quad \text { Kazanımlar } \\
\bullet \quad \text { Öğrenme alanları } \\
\bullet \quad \text { Açıllamalar } \\
\bullet \quad \text { Etkinlik örnekleri } \\
\bullet \quad \text { Ölçme değerlendirme }\end{array}$ & $\begin{array}{cl}\text { Programın modeli; üç boyutlu güncel öğretim programı } \\
\qquad \quad \text { Öğrenme alanı } \\
\bullet \quad \text { Kazanımlar } \\
\text { • Açılamalar }\end{array}$ \\
\hline Kazanım ifadeleri öğrenci merkezlidir. & Kazanım ifadeleri öğrenci merkezlidir. \\
\hline $\begin{array}{l}\text { Programda öğrenme alanı, kazanımlar, etkinlik örnekleri } \\
\text { birbirleriyle ilişkilendirilmiş ve bu ilişkilendirme eşliğinde } \\
\text { açılamalara yer verilmiştir. } \\
\text { Öğretim yöntemi? (Geleneksel, çağdaş) }\end{array}$ & $\begin{array}{l}\text { Programda öğrenme alanı, kazanımlar, etkinlik örnekleri } \\
\text { birbirleriyle ilişkilendirilmiş ve bu ilişkilendirme eşliğinde } \\
\text { açıklamalara yer verilmiştir. }\end{array}$ \\
\hline Programda örnek etkinliklere yer verilmiştir. & Programda örnek etkinliklere yer verilmemiştir. \\
\hline Programda ders işleyişine örnek verilmiştir. & Programda ders işleyişine örnek verilmemiştir. \\
\hline $\begin{array}{l}\text { Programda ölçme-değerlendirme durumlarına ilişkin örneklere yer } \\
\text { verilmiştir. }\end{array}$ & $\begin{array}{l}\text { Programda ölçme-değerlendirme durumlarına ilişkin örneklere yer } \\
\text { verilmemiştir. }\end{array}$ \\
\hline
\end{tabular}

Tablo 4'de görüldüğü gibi iki programda da ortak öğrenme boyutları (öğrenme alanları, kazanımlar, açıklamalar) yer alırken, 2009 ortaöğretim müzik dersi öğretim programının etkinlikler ve ölçme değerlendirme olmak üzere iki boyutu daha mevcuttur. İki programda da kazanım ifadeleri öğrenci merkezlidir. İki programında kazanımları, öğrenme alanları ve açıklamaları kendi içinde bir bütün oluşturmaktadır. 2009 ortaöğretim müzik ders öğretim programında bulunan örneklendirmeler 2018 ortaöğretim programında bulunmamaktadır.

Tablo 5

2009 Ortaögretim Müzik Dersi Öğretim Programı ve 2018 Ortaögretim Müzik Dersi Öğretim Programlarının Temel Beceriler ve Değerler-Alana Özgü Beceriler Boyutunda Karşılaştırılması

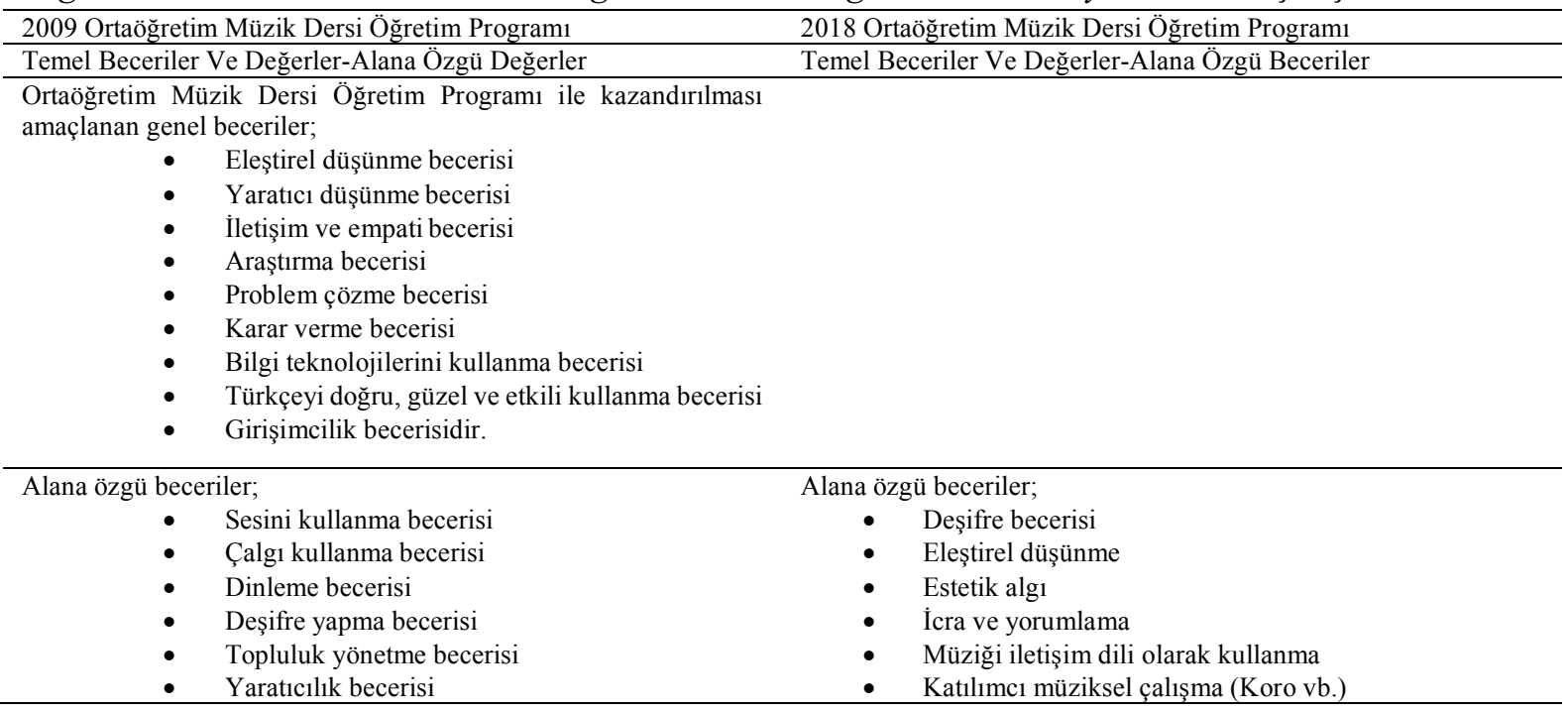


- Makamsal ve tonal ayırt edicilik

- Müzik terminolojisini doğru ve yerinde kullanma

- Sahne ve performans becerisi

- Müzik teknolojilerini kullanma

Tablo 5'de görüldüğü gibi iki programda da öncelikle müziği öğrenme, sonrasında müzik yoluyla bazı becerilerin kazandırılması amaçlanmıştır. 2009 ortaöğretim müzik dersi öğretim programında, müziğin diğer alanlara etkisi üzerine kazandırılmak istenen beceriler üzerine ayrıca durulmuştur. Alana özgü beceriler benzerlik göstermektedir. Buna karşın, 2018 ortaöğretim müzik dersi programına makamsal ve tonal ayırt edicilik ve müzik teknolojilerini kullanma konusu eklenmiştir.

Tablo 6

2009 Ortaöğretim Müzik Dersi Öğretim Programı ve 2018 Ortaöğretim Müzik Dersi Öğretim Programlarının Kazanımlar Boyutuna İlişkin Karşılaştırılması

\begin{tabular}{ll}
\hline 2009 Ortaöğretim Müzik Dersi Öğretim Programı & 2018 Ortaöğretim Müzik Dersi Öğretim Programı \\
\hline Programda Yer Alan Kazanımlar & Programda Yer Alan Kazanımlar \\
2009 Ortaöğretim Müzik Dersi Öğretim Programında yer alan & 2018 Ortaöğretim Müzik Dersi Öğretim Programında yer alan \\
kazanımlar; & kazanımlar; \\
9.sınıf :34 kazanım & 9. sınıf: 25 kazanım \\
10.sınıf:31 kazanım & 10. sinıf:22 kazanım \\
11.sınıf:32 kazanım & 11. sınıf:24 kazanım \\
12.sınıf:24 kazanım & 12. sınıf:21 kazanım \\
Toplam:121 kazanım & Toplam: 92 kazanım \\
\hline
\end{tabular}

Tablo 6'ya bakıldığında, 2009 ortaöğretim müzik dersi öğretim programında yer alan 121 kazanımın, 2018 ortaöğretim müzik dersi öğretim programında 92'ye düştüğü tespit edilmiştir. Buna rağmen, birçok kazanımın benzer olduğu ve güncellenen programda yer aldığı görülmektedir. 2009 ortaöğretim müzik dersi programında görülen ortalama kazanım sayısı yaklaşık olarak 30 iken, 2018 ortaöğretim müzik dersi öğretim programında bu sayı 25 civarıdır. Bazı kazanımların birleştirilerek sürdürülmesi, bazılarının kaldırılması sebebiyle bu sayı farkı ortaya çıkmıştır.

Tablo 7

2009 Ortaöğretim Müzik Dersi Öğretim Programı ve 2018 Ortaögretim Müzik Dersi Öğretim Programlarının Öğrenme-Öğretme Süreci ve Uygulama Boyutunda Karşılaştırılması

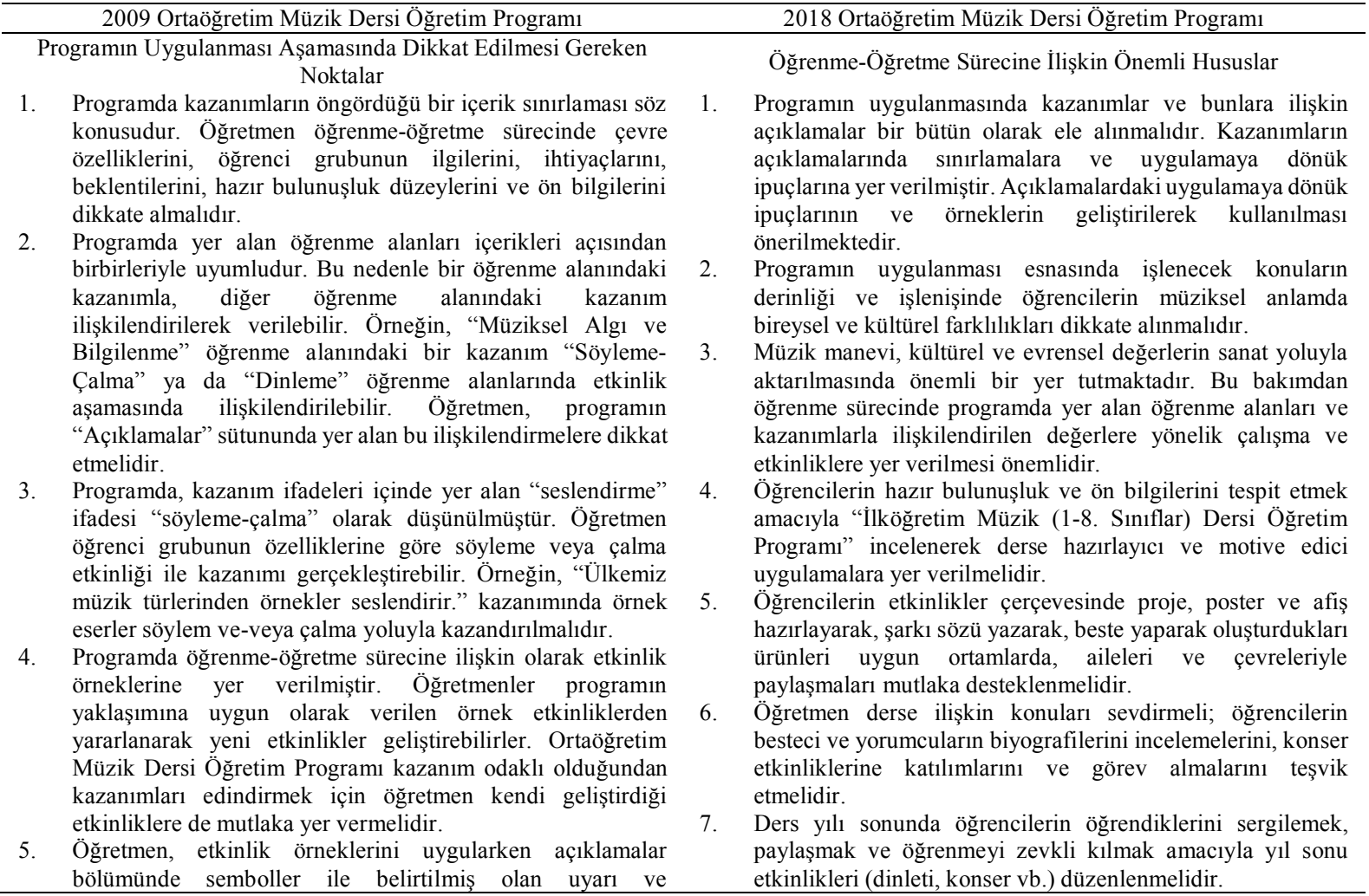


ilişkilendirmelere mutlaka dikkat etmelidir.

6. Ortaöğretim Müzik Dersi Öğretim Programı içinde yer alan müzik dersi öğrenme- öğretme süreci örnekleri (bk.s.35) dersin ișleniși ile ilgili örnekler olarak düșünülmelidir. Programın sonunda Ek 2'de yer alan etkinlik örnekleri ise öğretmene yol göstermesi amacıyla öğrenme-öğretme sürecini destekleyen etkinlik örnekleri olarak düşünülmelidir.

7. Öğrencilerin hazır bulunusluk ve ön bilgilerini tespit etmek amacıyla "İlköğretim Müzik (1-8. Sınıflar) Dersi Öğretim Programı" incelenerek derse hazırlayıcı ve motive edici uygulamalara (etkinliklere) yer verilmelidir.

8. Müzik dersi için oluşturulacak yıllık plan, ilgili dersin zümre öğretmenleri tarafından öğretim yılı başında yapılacak toplantı ile müzik dersi öğretim programının içeriğinde yer alan kazanımların her birini kapsayacak şekilde yapılmalıdır.

9. Öğretmen, programda yer alan ölçme değerlendirme tekniklerinden yararlanarak öğrencileri en iy değerlendirebileceğini düșündüğü kazanımları belirlemelidir. Ayrıca, hangi kazanıma yönelik değerlendirme yapacağını ve hangi ölçme değerlendirme tekniğini kullanacağını da kendisi belirlemelidir. Değerlendirmenin, öğrenmenin ayrılmaz bir parçası olduğunu bilmeli ve sadece ürünü değil öğrenme sürecini de değerlendirmelidir.

10. Öğretmen, değerlendirme yaparken geleneksel yöntemlerle alternatif değerlendirme yöntemlerini birlikte kullanmalıdır. Bu değerlendirme yöntemleri ve araçları; gözlem, performan görevleri, görüşmeler, öz değerlendirme ölçekleri, öğrenci ürün dosyaları (portfolyo), projeler ile çoktan seçmeli, esleștirmeli, boşluk doldurmalı, açık uçlu sorulardan oluşan testlerdir. Öğretmen, geleneksel değerlendirme yöntem ve araçlarını kullandığında öğrencilerde ıraksal düşünmeye yol açan özellikte sorular sormalıdır.

11. Öğretmen, öğrencilerin yapacağı sunumlarda tam öğrenmenin gerçekleşebilmesi için sunum sonunda mutlaka konuyla ilgili eksik kalabilecek yerleri açıklamalıdır.

12. Ders içi ilișkilendirmeler yapılırken ilgili öğrenme alanları arasındaki ilişkilendirmelerde uygulamalı etkinliklere öncelik verilerek bilgi aşamasına en son ulaşılmalıdır.

13. Her öğrenci müzik dersi ile ilgili bir dönem boyunca en az bir performans görevi hazırlamalıdır.

14. Öğrencilerin etkinlikler çerçevesinde fotoğraf çekerek, proje, poster ve afiş hazırlayarak, şarkı sözü yazarak, çalg1 yaparak, beste yaparak oluşturdukları ürünleri uygun ortamlarda, aileleri ve çevreleriyle paylaşmaları mutlaka desteklenmelidir.

15. Öğretmen fotoğraf, poster, resim, film, ses ve görüntü cihazları vb. araç ve gereçler ile bilișim teknolojilerini (İnternet gibi) imkânları ölçüsünde dersin bir parçası yapmalı ve öğrencileri eğitim-öğretim sürecinde bu kaynaklardan faydalanmaları yönünde motive etmelidir.

16. Öğretmen, öğrencilere millî, ahlaki, insani, manevi, kültürel değerler bakımından besleyici; demokratik, laik ve sosyal bir hukuk devleti olan Türkiye Cumhuriyeti'ne karşı görev ve sorumluluklarını yerine getirmede yol gösterici olmalıdır.

17. Öğretmen derse ilișkin konuları sevdirmeli; öğrencilerin besteci ve yorumcuların biyografilerini incelemelerini, konser etkinliklerine katılmalarını ve görev almalarını teşvik etmelidir.

18. Ders yılı sonunda öğrencilerin öğrendiklerini sergilemek, paylașmak ve öğrenmeyi zevkli kılmak amacıyla yıl sonu etkinlikleri düzenlenmelidir.
8. Öğretmenler, sadece ders kitaplarına bağlı kalmamalıdırlar. Sınıf düzeyi, öğrencilerin ilgi, hazırbulunuşluk düzeyleri, öğrenme stilleri gibi unsurları göz önünde bulundurarak kazanımlarla tutarlı olacak şekilde öğretim materyalleri (müzik notaları, müzik yazılımları, bilişim teknolojisi araçları, görsel ve ișitsel materyaller, dinleti, sunum, etkinlik, çalıșma kâğıtları, proje vb.) yapılandırmalı ve kullanmalıdırlar. Öğretim materyalleri hazırlanırken zümre öğretmenleri ve diğer disiplinlerin öğretmenleriyle iş birliği yapılmalıdır. Ayrıca EBA gibi kaynaklar takip edilerek alana ilişkin materyaller ve önerilen müzik yazılımları eğitim öğretim sürecine dâhil edilmelidir.

9. Öğrencilerden her sınıf düzeyinde türkü, şarkı vb. söyleme etkinliklerinden dengeli olarak sekiz eser seslendirmeleri sağlanmalıdır. Ayrıca EBA gibi kaynaklar takip edilerek ilgili müzik dağarcığı eğitim öğretim sürecine dâhil edilmelidir.

10. Nörobilim ve müzik psikolojisi bilim dallarında yapılan güncel çalıșmalar çalg1 eğitiminin beynin farklı işlev gören bölgelerini geliștirdiğini ortaya çıkarmıștır. Calgı eğitimi ile ilgili kurs, egzersiz vb. çalışmalara yönelik düzenlemeler müzik dersi zümre toplantılarında alınan kararlar ile belirlenmelidir. Dolayısıyla ders kitaplarında çalgı eğitimi ile ilgili içerik beklenmemekle birlikte çalgı eğitimi her sınıf düzeyinde öğrencilerin talep ve yetenekleri doğrultusunda dikkate alınmalı ve öğrencilere bu yönde uygun rehberlik yapılmalıdır.

11. Sıralı kazanımlardan anlaşılması gereken kazanımların takip eden haftalarda ișlenmesi zorunluluğu değil, sadece etkili müzik eğitimi için kendi içlerinde belirtilen öncelik sonralık sırasına uyulmasına dikkate edilerek işlenmesidir. Ayrıca kazanımlar, başka ders ișlenis süreçlerinde farklı kazanımlarla ders ilişkilendirme yapılarak tekrar verilebilir.

12. Öğrenme alanları içerikleri bakımından birbirleriyle tamamen kenetli olup sadece gerekli hallerde ayrılabilirler. Konuların işlenişinde birbiri ile ilişkili olan farklı öğrenme alanları ve kazanımları öğrencilerin gelișim düzeyleri ve bireysel farklılıkları göz önünde bulundurularak bir arada işlenmelidir. Dolayısıyla bir konu ișlenișinde aynı sınıf seviyesindeki tüm öğrenme alanlarından kazanımlar bir arada kullanılabilir. Kazanımlar yeri geldikçe farklı kazanımlarla ilişkilendirme yapılarak tekrar verilebilir. Ayrıca aynı sınıf seviyesindeki diğer derslerle de uygun kazanımlarda disiplinler arası ilişkilendirmeler yapılmalıdır.

Tablo 7'de her iki programın uygulanma süreçlerine ilişkin önemli hususlar vurgulanmaktadır. Her iki programda da, kazanımların birbiri ile örtüşük olduğu, bu sebeple uygulamada dikkat edilmesi gerektiği vurgulanmıştır. Ayrıca, her iki programda da öğretmenin rolüne yönelik bazı hususlar görülmektedir. Her iki programda da öğrencilerin hazır bulunuşluk düzeyine dikkat edilmesi gerekliliği vurgulanmıştır. Her iki programda da, öğrencinin ders içi ve ders içi etkinliğe yönlendirilmesi önerilmektedir. Her iki programda da öğrencinin durumu ile ilgili öğretmenin rolü üzerinde özellikle durulmuş, öğrencinin durumuna göre eğitim sistemini belirleme işinin öğretmene bırakılması önerilmiştir. 


\section{Sonuç}

Türk eğitim sisteminde, yapılandırmacı yaklaşımın benimsenmesinden sonra, programın ön plana çıkmasından ziyade öğretmenin etkinliğinin artması hedeflenerek programlar hazırlanmıştır. $\mathrm{Bu}$ araştırmanın ele aldığı programların ikisinde de yapılandırmacı yaklaşım benimsenmiş, öğretmenin yetkinliğinin artırılması sonucu programın da etkinliğinin artacağı öngörülmüştür.

Araştırmanın sonucunda, iki program arasında ortaya çıkan bazı farklılıklar gözlemlenmiş, bununla birlikte 2009 ortaöğretim müzik dersi öğretim programının 2018 ortaöğretim müzik dersi öğretim programına bir harita oluşturduğu ve yeni uygulamaya konulan 2018 ortaöğretim müzik dersi öğretim eski program ile benzerliklerinin olduğu da gözlemlenmiştir. Ayrıca bazı alanlarda değişikliklere gidilmiş, bazı alanlar kısaltılmıştır.

Araştırma sonucunda ortaya çıkan başlıca farklar şu şekilde gözlemlenmiştir; 2009 ortaöğretim müzik dersi öğretim programında bulunan bazı kazanımlar, 2018 ortaöğretim müzik dersi öğretim programında yer almamıştır. Özel ihtisas komisyonu, 2009 ortaöğretim müzik dersi öğretim programında yer alırken, 2018 ortaöğretim müzik dersi öğretim programında yer almamaktadır.

Bunun dışında, genel anlamda, özellikle öğrenme alanları, her iki programın içerisinde önemli yere sahip olmuş, programlar bu kapsamda inşa edilmiştir. Ayrıca öğrenme alanları, iki programda da örtüşük ve birbirleriyle etkileşim içindedir. Bununla beraber, öğrenme alanlarında çalma konusunda bakış açısının değiştiği gözlemlenmiştir. 2009 ortaöğretim müzik dersi öğretim programında bulunan "söyleme-çalma ve dinleme" öğrenme alanları, 2018 ortaöğretim müzik dersi öğretim programında "çalma" öğrenme alanı çıkartılarak "söyleme-dinleme" öğrenme alanı olarak yer verilmiştir. 2009 ortaöğretim müzik dersi öğretim programında, çalg1 eğitimi, programla ilgili dikkat edilecek hususlar başlığı altında, zümre toplantılarında karar verilmek üzere öğretmenin kendisine bırakılmıştır. Bunun sebebinin, özellikle önceki dönemlerde okul çalgısı olarak kullanılan blok flütün etkin bir müzik eğitim aracı olmamasının düşünülmesinden kaynaklandığı öngörülmektedir. Bunun bir sonucu olarak, müzik eğitiminde kullanılmak üzere, hem geleneksel hem de yeni okul çalgılarının araştırılması ve değerlendirilmesi ayrıca önerilmektedir.

Türkiye, hem tarih, hem de sosyo-kültürel açıdan zengin bir ülkedir. Müzik eğitimi alanında atılacak her adımın, Türk kültürünü yüceltmesi, milli duyguları üstün tutması, hem gelenekselliğe yer verirken, hem de çağdaşlıktan ödün vermemesi gerekmektedir. Bu bağlamda iki programın da benzer özellikler taşıdığı görülmektedir. Müziğin birleştirici unsur olmasından yararlanılarak yapılan eğitim planlamaları, ülkenin birlik ve beraberliği için önem taşımaktadır. Birlik ve beraberliğe duyulan ihtiyaç hiçbir zaman azımsanmamalıdır. Zira bu açıdan Türkiye, her zaman birlik ve beraberliğe önem vermiştir ve vermeye devam edecektir. Başarının anahtarı birleştirici olmaktır.

\section{Kaynakça}

Albuz, A. (2004). Eğitim/müzik eğitiminde program değerlendirme yaklaşımına genel bir bakış. Uludağ Üniversitesi Eğitim Fakültesi Dergisi, $17 \quad$ (1), 13-18. Erişim adresi: http://dergipark.gov.tr/download/article-file/153229

Bilen, S. (1995). İşbirlikli öğrenmenin müzik öğretimi ve güdüsel süreçler üzerindeki etkileri (Doktora Tezi). YÖK Tez veri tabanından erişildi (Tez no: 41285).

Brooks, J. G., \& Brooks, M. G. (1999). The Constructivist Classroom. Educational Leadship November 1999, 57, 18-24. Erişim Adresi: http://www.ascd.org/publications/educationalleadership/nov99/vol57/num03/The-Courage-to-Be-Constructivist.aspx

Demirel, Ö. (2007). Eğitimde program geliştirme. Ankara: Pegem Yayınc1lık. 
Erden, M. (1995). Eğitimde program değerlendirme. Ankara: Pegem Yayınları.

Erden, M. (1998). Öğretmenlik mesleğine giriş. İstanbul: Alkım Yayınları.

Ertürk, S. (1979). Ĕgitimde program gelişstirme. Ankara: Yelkentepe Yayınları.

MEB. (2009). 2009 ortaögretim müzik dersi öğretim programı. Ankara: MEB Yayınları.

MEB. (2018). 2018 ortaögretim müzik dersi ögretim programı 9-12. Sinıflar. Ankara: Milli Eğitim Bakanlığı Yayınları.

Sönmez, V. (2005). Program geliştirmede ögretmen elkitabı. Ankara: Anı Yayıncılık.

Sönmez, V. (2010). Öğretim ilke ve yöntemleri. Ankara: Anı Yayıncılık.

Uçan, A. (2005). Müzik eğitimi temel kavramlar-ilkeler-yaklaşımlar. Ankara: Müzik Ansiklopedisi

Varış, F. (1994). Eğitimde program geliştirme teori ve teknikler. Ankara: Alkım Yayınları.

Yıldırım, A., \& Akar, H. (1999). Nitel araştırma yöntemleri. Ankara: Seçkin Yayıncılık.

Yıldırım, Ş., \& Şimşek, H. (2013). Sosyal bilimlerde nitel araştırma yöntemleri. Ankara: Seçkin Yayıncılik. 